DOI 10.47649/vau.2020.v58.i3.05

IRSTI 16.01.21

UDK $81-2$

\author{
A.Sultangubiyeva ${ }^{1}$ \\ ${ }^{1}$ Kh.Dosmukhamedov Atyrau University \\ Atyrau, Kazakhstan \\ E-mail: a.sultangubiyeva@ asu.edu.kz
}

\title{
SPEAKING VERBS AND THEIR DIFFERENT STUDY APPROACHES IN MODERN ENGLISH
}

\begin{abstract}
In linguistics, the study of speaking verbs, such as verbs of speech, communicative verbs is researched in different directions, both domestic and foreign scientists set themselves different tasks. They were studied from the point of view of their lexical and grammatical semantics, from the point of view of the syntactic properties of these verbs, at the functional level, in the aspect of the relationship between thinking and speech, the logical and semantic properties of speech verbs.

However, there are still no works in linguistics that consider the functional categorization of speaking verbs with a mechanism description for varying their categorical status from the standpoint of functional, semiological and prototypical approaches to the formation of the categorical meaning of predicative units.

The verbs say, tell, speak and talk carry one integral symptom "speaking", while the linguistic units have differential signs in their semantic meaning. In this regard, the verbs say, tell, speak and talk are attributed to the nuclear zone, and their synonyms are in the peripheral zones.

The concept of "speaking" in modern English can be objectified at the linguistic level in the most generalized form, stylistically neutralized by the verbs say, tell, speak and talk, which we define as prototypes of the concept study.
\end{abstract}

Keywords: verbs, concept, aspect, lexical units, lexical and grammatical semantics

Speaking verbs have been repeatedly the object of linguistic research, where their lexical and categorical semantics were studied as well as functioning in various structures. In linguistic literature, the nomenclature of the semantic structure is described quite well in considering group of verbs at the systematic and paradigmatic level, there are also data concerning the features of their functioning in the utterance sentence. However, there are not many works in linguistics that consider the functional speaking verbs categories with a description of the mechanism for varying their categorical status from the functional, semiological and prototypical approaches to the categorical meaning formation of predicative units. [1; p.96]

Speaking verbs are one of the most objects in linguistic research. Interest to this group of lexical units is due to both of their semantic structure and the ambiguity in the issue of identifying synonymous series and thematic groups.

Due to the fact that these cognitive features were identified in accordance to the semantic components of the synonymous series of the verbs say, tell, speak and talk separately, the interpretation of these features leads to the construction of a general model of the linguistic representation of the concept of "speaking". So, we can distinguish the main four groups of ways of research verb, namely:

1. "The manner of speaking" Speech is characterized as a sound image endowed with certain qualities. Physical characteristics include: tonality (high, low), loudness (loud, quiet), vocal characteristics (sonorous, hoarse, whispering), tempo (fast, slow), quantity (a lot, little) and articulation (with defects, clearly, illegible).

2. "Presentation form". It indicates the form of expression of thoughts, for example: describe - cunaтmay, описывать, inform - хабарлау, информировать, 
manifest - өңдеу, жариялау, обнародовать, провозглашать, declare - жариялау, объявлять, mention - aman өту, упоминать. This group can also include linguistic units that have a negative emotional connotation in their meaning: patter - днзімелесу, тараторить, gabble - тырсылдату, трещать, palaver-мақтау, льстить.

3. "Attitude". The speaking process suggests a type of social relationship itself. This aspect characterizes the speech activity of the speaker as a connection between people, based on the common interests of the participants in situation: chat әңгімелесу, болтать, converse - байланыста болу, поддерживать отношения, discuss - талқылау, обсуждать, instruct - нұсқау беру, инструктировать, requеst - сұрау, просить, give away - aшып аümy, раскрыться, confess - мойындау признаваться.

4. "Target setting". The communicative purpose of the statement is determined in this aspect. Here we can distinguish such signs as "speaking as a hint", "speaking as a conviction", "speaking as advice", "speaking as an assessment", "speaking as spending time" and "speaking as harming": attest - айвақ беру, свидетельствовать, depose сендіру, уверять, warrant - ескерту, предупреждать, insinuate - меңзеу, намекать, introdисе - таныстыру, представлять, ргороле - ұсыну, предлагать, dictate - нұсқау беру, диктовать, imply - мецзеу, подразумевать. [2; р.310]

Thus, the concept of "speaking" in modern English can be objectified at the linguistic level in the most generalized form, stylistically it is neutralized by the verbs say, tell, speak and talk, which we define as prototypes of the concept under the research. The given semantic components are included in the core of the nominative field. Differential components are also highlighted, expressed by their synonyms. These language units are included in the peripheral zones of the analyzed field. The field organization of the concept reflects the hierarchy of individual cognitive features. The division of the concept content into the core and the periphery is carried out according to the intensity criterion of cognitive features.

The analysis of the dominant verbs of the Kazakh, English and Russian languages айту, сөйлеу - say, speak - говорить, сказать shows that they implement the substitute function in the same way. The more dominants of the lexical-semantic group of speech verbs are able to replace verbs, that is higher pragmatic significance.

The object of analysis was the verbs denoting only the process of speech in its pure form for a long time. On the other hand, verbs that implement some activity in the act of speech, which were excluded from the range of those considered. This approach have considered that speech verbs denote an action (in a broad sense) performed by the vocal apparatus, that is, the pronunciation of articulate sounds (individual words or phrases) in the process of verbal communication. Two main groups were distinguished in the thematic group of verbs containing an indication of the speech process for a long time:

a) verbs, which are denoting the actual process of speech and its main functions (message, conversation, story): tell, say, speak, talk.

b) verbs, which are denoting any other action that can be implemented in the process of speech (oral or written): command, order, affirm, repeat.

The study of speaking verbs (speech verbs, communicative verbs) were in different directions, both national and foreign scientists put different tasks before themselves in linguistics. This class of verbs were studied from the point of view of their lexical and grammatical semantics, the syntactic properties of these verbs at the functional level in the aspect of the relationship between thinking and speech, and also the logical and semantic properties of speech verbs. 
First of all the verbs denoting the actual process of speech can be divided into two subgroups:

1. Verbs, which there are a designation of one of the speech process functions in its pure form, without additional characteristics:

a) verbs, which are the most general designation of the speech process: tell, say, speak, talk.

b) verbs, which are narrower designation of the speech process: narrate, express, repeat, declare.

2. Verbs containing an additional characteristic of the speech process are its duration, beginning, end, sound strength, pronunciation clarity, and so on. As a rule, verbs with additional adverbial words characterizing the process, which are distinguished here.

In a typical speech situation, including the speaker, the listener and the speaker's utterance are associated with a wide variety of types of acts. When speaking, the speaker puts the speech apparatus in motion and pronounces sounds. At the same time, it performs other acts: informs the listeners, or causes them irritation or boredom. It also carries out acts consisting in the mention of certain person, places. In addition, the speaker makes a statement or asks a question, gives a command or reports, congratulates or warns, that is, performs an act from among them, that Austin called illocutionary.

Examples of English verbs associated with illocutionary acts are: state - бекіту, «излагать, констатировать», assert - мәлімдеу, «утверждать, заявлять», describe - cunaтmay «описывать», warn - ескерту, «предупреждать», reтаrk байқ̧ау, «замечать», соттепt - түсініктеме беру, «комментировать», соттапd бұйрық беру «командовать», order - тапсырыс беру, «приказывать», requеst сұрау, «просить», approve - бекіту, «одобрять». [2; p.310]

The main speaking verbs include the verbs say, tell, speak, talk. Here are their semantic characteristics. The semantics of the verbs belonging to the synonymous groups of the verb say is based on the meaning of information. The total number of synonyms of the verb say consists of 92 lexical units, which are in four synonymous series. Each of the constituents included in the synonymous series, and conveys a separate differential feature and is characterized by an additional semantic coloring.

Thus, the analysis of the semantics of the nominative field core, including the direct nomination of the research concept, namely the verb say, allowed us to single out the following semantic components: "to express thoughts verbally; to express an opinion; give examples; testify, point to something":

The first time to say you loved me and missed me and were longing to come back to me and would I wait for you and there wasn't anyone else was there [3; p.46].

Speaking verbs with a simple semantic structure tend to expand their semantics in syntagmatics by specifying: say, tell, ask, talk, speak, answer. Example: Dora began to say something to him, but he went off without looking at her.; Yet she had only to speak a few quiet words, put a finger on his sleeve placatingly.; He went instead to the Headmaster and told him the whole story.; He hefted the gun in his hand and asked a question with knitted black eyebrows.

Yu.D. Apresyan uses a detailed and expanded nomenclature of speech acts. His basic thesis is that the performative formula before performative verb. That is, the meaning of the performativity of a verb have determined by the performative context, therefore, the main properties of performative verbs are motivated by the primary properties of performative statements: impermanence, equivalence to action, intentionality, uniqueness, etc. 
He also argues that the verb "speak" is not purely performative, and in a sentence such as "I say that he is mistaken," it performs an anaphoric function, referring to what is already said before this act of speech. [4; p. 212]

Semantic verbs say, tell, speak and talk carry one integral feature "speaking", while other linguistic units have differential features in their semantic meaning. In this regard, the verbs say, tell, speak and talk are assigned to the nuclear zone, and their synonyms are to the peripheral zones.

Due to the fact of these cognitive features were identified in accordance with the semantic components of the synonymous series of the verbs say, tell, speak and talk separately, the interpretation of these features leads to the construction of a general model of the linguistic representation of the "speaking" concept.

Thus, the "speaking" concept in modern English can be objectified at the linguistic level of the most generalized form, stylistically neutralized by the verbs say, tell, speak and talk, which we define the concept as prototypes.

\section{References}

1 Bakhtina V.P. Lexical and grammatical compatibility of verbs of speech in the Russian literary language of the 2nd half of the 19th century. Author's abstract. Thesis of. Candidate of philological sciences. Voronezh, 1965.

2 Voronkov S.A. The pragmatic aspect of English speaking verbs "speak, talk, say, tell" // Scientific. app. Sib. acad. state service. - Novosibirsk, 2000. - T. 3. - S. 304-321.

3 Ross J.R. On Declarative Sentences. // Readings in English Transformational Grammar. Waltham, Moss: Ginn, 1970.

4 Apresyan Yu.D. Performatives in grammar and dictionary // Academy of Sciences of the USSR. Series of literature and languages, 1986, vol. 45, No. 3. S. 208-224.

5 Janitor O.D. Functional categorization of speaking verbs in modern English. Author's abstract. Dissertation of doctor of philological sciences. Belgorod, 2003.

6 Babushkina A.P. Concepts types in the lexical and phraseological semantics. Voronezh, Voronezh State University, 2008. - 104 p.

7 Lewontin I.B. Speech and language in modern Russian // Speech Languages. Sat papers / Society. hands. and ed. N.D. Arutunova. - Moscow: Languages of Russian Culture, 2000. - C. 271-289. I.B.

8 The Concise Oxford Dictionary of Proverbs. Oxford, New York. Oxford University Press. Third edition, 1998.

\section{ГЛАГОЛЫ ГОВОРЕНИЯ И РАЗЛИЧНЫЕ ПОДХОДЫ К ИХ ИЗУЧЕНИЮ В СОВРЕМЕННОМ АНГЛИЙСКОМ ЯЗЫКЕ}

В лингвистике исследование глаголов говорения (глаголов речи, коммуникативных глаголов) шло по разным направлениям и отечественные, и зарубежные ученые ставили перед собой разные задачи. Они изучались с точки зрения их лексической и грамматической семантики, с точки зрения синтаксических свойств данных глаголов, на функциональном уровне, в аспекте соотношения мышления и речи, с точки зрения логико-семантических свойств глаголов речи.

Однако до сих пор в лингвистике нет работ, рассматривающих функциональную категоризацию глаголов говорения с описанием механизма варьирования их категориального статуса с позиций функционально - семиологического и прототипического подходов к формированию категориального значения предикативных единиц.

Глаголы say, tell, speak u talk несут в себе один интегральный симптом «говорение», в то время как остальные языковые единицы имеют в своем семантическом значении дифференциальные признаки. В связи с этим, глаголы say, tell, speak u talk отнесены к ядерной зоне, а их синонимы - к периферийным поясам.

Концепт «говорение» в современном английском языке может быть объективирован на языковом уровне в наиболее обобщенном виде, стилистически нейтрализовано глаголами say, tell, speak и talk, определяемые нами как прототипы исследуемого концепта.

Ключевые слова: глаголы, концепт, аспект, лексические единицы, лексическая и грамматическая семантика 


\title{
СӨЙЛЕУ ЕТІСТІКТЕРІ ЖӘНЕ ОЛАРДЫН ҚАЗІРГІ АҒЫЛШЫН ТІЛІНДЕ ОҚЫТУДЫН ӘРТУРЛІ ТӘСІЛДЕРІ
}

Тіл білімінде сөйлеу етістігін, соның ішінде сөйлеу етістігі, коммуникативті етістікті зерттеу әр түрлі бағытта жүрді, отандық та, шетелдік ғалымдар да алдарына әр түрлі міндеттер қойды. Олар өздерінің лексикалық және грамматикалық семантикасы тұрғысынан, осы етістіктердің синтаксистік қасиеттері тұрғысынан, функционалдық деңгейде, ойлау мен сөйлеу арасындағы байланыс аспектісінде, сөйлеу етістігінің логикалық және семантикалық қасиеттері тұрғысынан зерттеуде.

Алайда, тілдік етістіктерде сөйлеу етістігінің функционалды категориясын олардың категориялық статусын предикативті бірліктердің категориялық мағынасын қалыптастыруға функционалдық, семиологиялық және прототиптік тәсілдер тұрғысынан өзгерту механизмін сипаттай отырып қарастыратын бірде-бір еңбек жоқ.

Say, tell, speak u talk (айту, сөйлеу) етістіктері «сөйлеудің» бір ажырамас симптомына ие, ал қалған тілдік бірліктердің мағыналық мағынасында дифференциалды белгілер бар. Осыған байланысты say, tell, speak u talk (айту, сөйлеу) етістіктері ядролық аймаққа жатады, ал олардың синонимдері сыртқы аймақтарға жатады.

Қазіргі ағылшын тіліндегі «сөйлеу» тұжырымдамасын лингвистикалық деңгейде неғұрлым жалпыланған түрде объективтеуге болады, стильдік тұрғыдан бейтарапталған Say, tell, speak u talk (айту, сөйлеу) етістіктері арқылы зерттеп отырған тұжырымдаманың прототиптері ретінде анықтауға болады.

Негізгі сөздер: етістіктер, ұғым, аспект, лексикалық бірліктер, лексикалық және грамматикалық семантика

\section{Information about authors}

Aigul Sultangubiyeva, Candidate of Philological Sciences, Associate Professor of Thanslation Studies and Foreign Languages Deaprtment, Kh.Dosmukhamedov Atyrau University, Atyrau, Kazakhstan, e-mail: a.sultangubiyeva@asu.edu.kz

DOI 10.47649/vau.2020.v58.i3.06

FTAMP 16.31 .51

ӘОЖ 811.512.122

\author{
А.У. Мырзабай ${ }^{1}$ \\ ${ }^{1}$ Қазақ ұлттық қыздар педагогикалық университеті \\ Алматы қ., Қазақстан Республикасы \\ E-mail: myrzabay.aidana@mail.ru
}

\section{ҚОСТІЛДІЛІК ЖАҒДАЙЫНДА ҚАЗАҚ ТІЛІН ЕКІНШІ ТІЛ РЕТІНДЕ ОҚЫТУДЫН ПАРАДИГМАСЫ}

\begin{abstract}
Мақалада мемлекеттік тіл - қазақ тілін билингвизм жағдайында екінші тіл ретінде оқытудың парадигмасы жүйеленген. Тіл үйретудегі жаңа технологиялар, замануи әдіс-тәсілдерді ойлап тауып, қолданысқа енгізіп, нәтижеге жету - бүгінгі тіл үйрену мен тіл үйрету процесіндегі өзекті мәселелердің бірі болып табылады. Жылдан жылға халықаралық-мәдениетаралық коммуникацияның шеңбері кеңейіп, қарқындау үстінде болғандықтан, тіл үйрену мен тіл үйретуге деген сұраныс артып, лингвистика мен методиканың интеграциясынан жаңа челлендждер талап етілуде. Бұл челленждердің басты бағыты - «тілді қалай жедел үйренуге болады?», «тілді үйрену жеңіл болуы үшін, қандай әдіс оңтайлы?» деген негізгі аспектілерді қамтып, тіл үйрету методикасының қоржыны жаңа, заманауи технологиялар мен әдіс-тәсілдермен толығу үстінде. Дегенмен, бұлардың көпшілгі қазіргі тіл үйрету методикасында айтарлықтай нәтижеге жеткізе алмай отыр. Өйткені, тіл үйрету барысында тыңдаушының ана (бірінші) тілімен салыстырасалғастыра отырып үйрету негізігі принцип болып, оқытылып жатқан тілдің өзіне ғана тән ерекшеліктері екінші орында қалып жатады. Сол себепті де, зерттеу барсында қазақ тілін екінші тіл ретінде оқытудағы парадигма - тілді үйренудегі табиғи механизмдерді қолдана отырып, тілдің
\end{abstract}

